\title{
Leafy Spurge Control and Herbicide Residue From Annual Picloram and 2,4-D Application
}

\author{
RODNEY G. LYM AND CALVIN G. MESSERSMITH
}

\section{Abstract}

Annual application of picloram (4-amino-3,5,6-trichloro-2-pyridinecarboxylic acid) and picloram plus 2,4-D [(2,4-dichlorophenoxy)acetic acid] and biannual application of 2,4-D for 5 consecutive years was evaluated for leafy spurge (Euphorbia esula L.) control. The picloram treatments were evaluated for soil residue. The experiment was located at 2 sites in eastern North Dakota and 1 site in western North Dakota on various soil types. Picloram at $0.28,0.42$, and $0.56 \mathrm{~kg} / \mathrm{ha}$ provided 48,75 , and $90 \%$ leafy spurge control after 4 annual treatments, respectively. Control increased to 85 and $91 \%$ when $2,4-\mathrm{D}$ at $1.1 \mathrm{~kg} / \mathrm{ha}$ was added to the annual treatment of picloram at 0.28 and $0.42 \mathrm{~kg} / \mathrm{ha}$, respectively. However, 2,4-D with picloram at $0.56 \mathrm{~kg} / \mathrm{ha}$ did not increase leafy spurge control compared to picloram alone.

Picloram did not accumulate in the upper $15 \mathrm{~cm}$ of the soil profile and generally was not detected above the 2 ppbw level 12 months following each annual application. Greater picloram residue was found deeper in sandy than clay soil and in soil with high compared to low organic matter. Picloram at 500 and 250 ppbw was required to reduce leafy spurge seedling emergence and subsequent survival by $50 \%$, respectively. However, picloram at $125 \mathrm{ppbw}$ reduced leafy spurge regrowth from root segments of 4 lengths to near zero. Picloram at 8 to $32 \mathrm{ppbw}$ stimulated leafy spurge seedling emergence compared to the control. Annual application of picloram at low rates gradually controlled leafy spurge, but picloram soil residues were not high enough to control subsequent seed germination and shoot regrowth from roots.

Key words: herbicide interaction, Euphorbia esula L., HPLC

Picloram (4-amino-3,5,6-trichloro-2-pyridinecarboxylic acid) is the most effective herbicide for control of leafy spurge (Euphorbia esula L.) (Lym and Messersmith 1985a). Picloram at $2.2 \mathrm{~kg} / \mathrm{ha}$ has given $80 \%$ leafy spurge control 27 months after application in North Dakota and for 36 to 39 months in Wyoming (Alley et al. 1983). The cost of picloram at $2.2 \mathrm{~kg} /$ ha is often $50 \%$ or more of the total land value and 8 to 10 times higher than the cash rent value of pasture and rangeland (Johnson 1984). Thus, it often is not economical to control leafy spurge with high rates of picloram on large infestations in pasture and rangeland.

2,4-D [(2,4-dichlorophenoxy)acetic acid] dimethylamine at 1.1 $\mathrm{kg} / \mathrm{ha}$ enhanced leafy spurge control when applied with picloram at $0.6 \mathrm{~kg} / \mathrm{ha}$ or less (Lym and Messersmith 1985a). Annual treatment of picloram at 0.3 to $0.6 \mathrm{~kg} /$ ha with 2,4-D at 0.3 to $1.1 \mathrm{~kg} / \mathrm{ha}$ gradually improved leafy spurge control to $80 \%$ or better after 3 years. This combination treatment also increased forage production up to $71 \%$ and reduced leafy spurge yield by $96 \%$ after 3 annual applications in North Dakota (Lym and Messersmith 1985b).

Annual application of picloram could become an environmental hazard because of long persistence, relatively high water solubility and leaching potential, and high phytotoxicity. However, residue from picloram applied at $0.56 \mathrm{~kg} /$ ha or less generally does not persist in the environment. Herr et al. (1966) found that the highest picloram concentration in heavy to medium textured soil following annual application was near the surface but picloram residue was much deeper in light textured soil. Picloram dissipated faster at

\footnotetext{
Authors are assistant professor and professor of agronomy, North Dakota State University, Fargo, N.D. 58105.

Published with the approval of the Director, Agricultural Experiment Station, North Dakota State University as Journal Article No. 1480.

Manuscript accepted 24 September 1986.
}

low than high application rates on all 3 soil types. Picloram applied on rangeland generally has dissipated rapidly with the highest concentration remaining in the top $15 \mathrm{~cm}$ of the soil profile (Scifres et al. 1977). Picloram applied at $0.28 \mathrm{~kg} /$ ha or less often dissipated within 60 days (Bauer et al. 1972; Scifres et al. 1971a, 1971b). Picloram at $2.2 \mathrm{~kg} / \mathrm{ha}$ applied 5 times in 2 years did not accumulate in the vegetation, soil profile, or well water on the prairie ecosystems of central Texas (Bovey et al. 1974, 1975).

The purpose of this study was to evaluate various annual picloram and 2,4-D treatments for leafy spurge control and determine picloram soil residue and effect on seedling emergence and growth in 3 areas of North Dakota following a 5-year annual treatment program.

\section{Materials and Methods}

An experiment to evaluate leafy spurge control from annual applications of picloram and picloram plus 2,4-D and biannual application of 2,4-D alone was established at 3 sites in North Dakota. The sites included a bluegrass (Poa spp.) pasture near Sheldon, a mixed grass prairie on a federal game management area near Valley City, both in eastern North Dakota, and a mixed grass pasture near Dickinson in western North Dakota. Soil properties and annual precipitation received during the study at each site are listed in Table 1 . All sites had at least an $80 \%$ ground cover of leafy spurge with few other forbs present.

Herbicides were applied using a tractor mounted sprayer delivering $75 \mathrm{~L} /$ ha water at $240 \mathrm{kPa}$. The experiment was begun on 25 August 1981 at Dickinson, 1 September 1981 at Sheldon, and 11 June 1982 at Valley City. All treatments were applied annually except 2,4-D alone which was applied biannually (twice per year). Picloram treatments were applied in late August 1981 and in June 1982 through 1985 . The 2,4-D biannual treatments were applied in June and August of each year. Thus, the Dickinson and Sheldon sites were sprayed with picloram and picloram plus 2,4-D treatments 5 times, and 2,4-D alone 8 times, while the Valley City site received 4 and 7 treatments, respectively. Herbicides were applied when leafy spurge was flowering in June or had resumed fall regrowth following a summer dormancy period in August. The plots were 3.1 by $9.1 \mathrm{~m}$ and each treatment was replicated 4 times in a randomized complete block at all sites. Evaluations were based on visual percent stand reduction as compared to the control.

Soil samples for picloram residue analysis were taken twice each year except 1985 at all locations. The first yearly sample was collected prior to herbicide application in June and the second in late August or early September from the untreated control and picloram-alone treated plots. Three subsamples $15-\mathrm{cm}$ deep were collected per plot and combined for each sampling date from 1982 through 1984. Four subsamples $120-\mathrm{cm}$ deep were collected per plot in September 1985 and divided into 5 segments consisting of 0 to 15,15 to 30,30 to 60,60 to 90 , and 90 to $120 \mathrm{~cm}$ depths and combined.

Picloram concentration was determined by bioassay using sunflower (Helianthus annuus L.) for samples collected from 1982 through 1984. Soil samples were forced-air-oven dried at $27^{\circ} \mathrm{C}$, screened to pass through a 4-mm mesh screen and divided into $500-\mathrm{g}$ subsamples. The standard curve was prepared by adding technical picloram at 2 to 250 ppbw to 4 replicate subsamples of untreated soil from each location and depth. Ten $\mathrm{ml}$ of water which 
Table 1. Physical and chemical characteristics of soils and annual precipitation at the various study sites in North Dakota.

\begin{tabular}{|c|c|c|c|c|c|c|c|c|c|c|c|c|c|c|c|c|c|}
\hline \multirow[b]{3}{*}{ Location } & \multirow[b]{3}{*}{ Soil type } & \multirow[b]{3}{*}{ Sand } & \multirow[b]{3}{*}{ Silt } & \multirow[b]{3}{*}{ Clay } & \multirow[b]{3}{*}{$\begin{array}{c}\text { Organic } \\
\text { matter }\end{array}$} & \multirow[b]{3}{*}{ pH } & \multirow[b]{3}{*}{$\begin{array}{c}\text { Cation } \\
\text { ex- } \\
\text { change } \\
\text { capacity }\end{array}$} & \multicolumn{10}{|c|}{ Precipitation } \\
\hline & & & & & & & & \multicolumn{2}{|c|}{1981} & \multicolumn{2}{|c|}{1982} & \multicolumn{2}{|c|}{1983} & \multicolumn{2}{|c|}{1984} & \multicolumn{2}{|c|}{1985} \\
\hline & & & & & & & & $\begin{array}{l}\text { Trt. } \\
\text { to } \\
\text { samp- } \\
\text { ling }\end{array}$ & Annual & $\begin{array}{c}\text { Trt. } \\
\text { to } \\
\text { samp- } \\
\text { ling }\end{array}$ & Annual & $\begin{array}{l}\text { Trt. } \\
\text { to } \\
\text { samp- } \\
\text { ling }\end{array}$ & Annual & $\begin{array}{l}\text { Trt. } \\
\text { to } \\
\text { samp- } \\
\text { ling }\end{array}$ & Annual & $\begin{array}{l}\text { Trt. } \\
\text { to } \\
\text { samp- } \\
\text { ling }\end{array}$ & Annual \\
\hline \multirow{2}{*}{ Sheldon } & \multirow[b]{2}{*}{$\begin{array}{l}\text { Hamar- } \\
\text { Uleh fine } \\
\text { sandy loam }\end{array}$} & 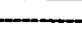 & - & $\pi$ & - & & (meq/ & \multirow[b]{2}{*}{$\begin{array}{c}27.1 \\
(166)\end{array}$} & \multirow[b]{2}{*}{58.3} & \multirow{2}{*}{\multicolumn{2}{|c|}{51.6}} & \multirow[b]{2}{*}{$\begin{array}{l}19.0 \\
(65)\end{array}$} & \multirow[b]{2}{*}{46.3} & \multirow{2}{*}{\multicolumn{2}{|c|}{53.5}} & - & \multirow[b]{2}{*}{38.2} \\
\hline & & 78 & 13 & 9 & 2.1 & 7.7 & 12.8 & & & & & & & & & $\begin{array}{l}15.3 \\
(76)\end{array}$ & \\
\hline $\begin{array}{l}\text { Valley } \\
\text { City }\end{array}$ & $\begin{array}{l}\text { Barnes } \\
\text { stony loam }\end{array}$ & 43 & 41 & 16 & 9.4 & 6.7 & 37.7 & & 45.0 & $\begin{array}{r}7.4 \\
(74)\end{array}$ & 45.4 & $\begin{array}{l}22.5 \\
(73)\end{array}$ & 36.0 & $\begin{array}{l}11.0 \\
(92)\end{array}$ & 38.8 & $\begin{array}{l}15.3 \\
(78)\end{array}$ & 42.0 \\
\hline Dickinson & Felor loam & 17 & 56 & 27 & 3.6 & 6.6 & 20.0 & $\begin{array}{c}47.0 \\
(167)\end{array}$ & 40.0 & $\begin{array}{l}13.3 \\
(86)\end{array}$ & 60.1 & $\begin{array}{l}14.5 \\
(72)\end{array}$ & 39.5 & $\begin{array}{l}20.8 \\
(90)\end{array}$ & 45.2 & $\begin{array}{c}13.0 \\
(105)\end{array}$ & 43.4 \\
\hline
\end{tabular}

Number in ( ) are the number of days from treatment to sampling each year.

Treatment applied fall 1981 and in June each year thereafter.

contained enough picloram to give the required concentration were added to each $500-\mathrm{g}$ soil sample, air dried for $18 \mathrm{~h}$, and thoroughly mixed. The samples for both the standard curve and field samples were placed in $11-$ by $11-$ by $5-\mathrm{cm}$ plastic pots, watered to $80 \%$ field capacity, and allowed to equilibrate for $24 \mathrm{~h}$. Eight sunflower seeds were placed on the soil surface and covered with $2 \mathrm{~cm}$ of styrofoam beads. The pots were arranged in a completely random design in a greenhouse at $24^{\circ} \mathrm{C}$, and natural light was supplemented by metal halide lights with an intensity of 450 $\mu \mathrm{E} \cdot \mathrm{m}^{-2} \cdot \mathrm{s}^{-1}$ for a $16-\mathrm{h}$ photoperiod. The pots were rerandomized weekly. Sunflowers were harvested after 30 days. The topgrowth was oven dried at $60^{\circ} \mathrm{C}$. A linear standard curve was calculated using regression analysis (Stat. Anal. Syst. 1982), and the mean sunflower dry weights for field samples were compared to those from known concentrations to estimate picloram concentration.

Picloram concentration from the samples collected in 1985 was determined by high pressure liquid chromatography (HPLC). Soil samples were dried and mixed as described earlier. Replicate $40-\mathrm{g}$ soil samples were placed in $250-\mathrm{ml}$ flasks, and then $80 \mathrm{ml}$ of acetonitrile/water/ammonium hydroxide $(70: 18: 12, \mathrm{v} / \mathrm{v} / \mathrm{v})$ were added and shaken for $0.5 \mathrm{~h}$. The soil samples were held at room temperature for $18 \mathrm{~h}$ and then shaken a second time for $0.5 \mathrm{~h}$ (Smith and Milward 1983). The sample was vacuum filtered through $6 \mu \mathrm{m}$ filter paper and the aqueous extract was evaporated to approximately $14 \mathrm{ml}$ with a rotary evaporator at $40^{\circ} \mathrm{C}$. The sample was brought to $40 \mathrm{ml}$ with $5 \%$ aqueous sodium carbonate (w/v) and centrifuged for $10 \mathrm{~min}$ at $10,000 \mathrm{rpm}$. The sample was filtered a second time through an $0.2 \mu \mathrm{m}$ glass fiber syringe filter and then brought to $100 \mathrm{ml}$ with the $5 \%$ sodium carbonate solution. The solution was transferred to a separatory funnel and extracted with $25 \mathrm{ml} N$-hexane. The inorganic fraction was discarded.

The aqueous phase containing picloram was acidified with $15 \mathrm{ml}$ concentrated sulfuric acid. The sample was further clarified by adding $1.5 \mathrm{ml}$ of saturated potassium permanganate and held at room temperature for $5 \mathrm{~min}$, after which $5 \mathrm{M}$ sodium bisulfite was added dropwise until the solution was colorless (Wells et al. 1984). The sample was extracted twice with $10 \mathrm{ml}$ of methylene chloride and the eluate was evaporated to dryness on a rotary evaporator. The concentrated sample was redissolved in $3 \mathrm{ml}$ of acetonitrile/water $(60: 40, v / v)$ and a $10 \mu \mathrm{L}$ injection of the eluate from this procedure was quantified by HPLC using a $\mathrm{C}-18$ reverse-phase cartridge $(0.45$ i.d. by $25 \mathrm{~cm})$. The solvent system consisted of:

Table 2. Leafy spurge control from five annual picloram or picloram plus 2,4-D treatments and eight biannual 2,4-D treatments at three locations in North Dakota.

\begin{tabular}{|c|c|c|c|c|c|c|c|c|c|c|c|}
\hline \multirow[b]{3}{*}{ Herbicide } & \multirow[b]{3}{*}{ Rate } & \multicolumn{6}{|c|}{ Site and 1985 evaluation date } & \multirow{2}{*}{\multicolumn{4}{|c|}{$\frac{\text { Mean }}{\text { Months after treatment }}$}} \\
\hline & & \multicolumn{2}{|c|}{ Sheldon } & \multicolumn{2}{|c|}{ Dickinson } & \multicolumn{2}{|c|}{ Valley City" } & & & & \\
\hline & & June & Aug & June & Aug & June & Aug & 12 & 24 & 36 & 48 \\
\hline & $(\mathrm{kg} / \mathrm{ha})$ & & & & & . & ontrol)- & & & & 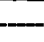 \\
\hline Picloram & 0.28 & 12 & 60 & 61 & 35 & 34 & 39 & 39 & 48 & 41 & 48 \\
\hline Picloram & 0.42 & 55 & 88 & 66 & 62 & 78 & 48 & 65 & 62 & 50 & 75 \\
\hline Picloram & 0.56 & 87 & 94 & 77 & 86 & 58 & 59 & 65 & 71 & 73 & 90 \\
\hline 2,4-D biannual & 1.1 & 31 & 61 & 44 & 43 & 23 & 31 & 22 & 30 & 35 & 52 \\
\hline 2,4-D biannual & 1.6 & 35 & 74 & 31 & 21 & 38 & 52 & 22 & 24 & 34 & 48 \\
\hline 2,4-D biannual & 2.2 & 51 & 87 & 29 & 21 & 41 & 46 & 19 & 30 & 35 & 54 \\
\hline Picloram+2,4-D & $0.28+1.1$ & 48 & 85 & 82 & 84 & 51 & 74 & 52 & 66 & 66 & 85 \\
\hline Picloram+2,4-D & $0.28+1.6$ & 72 & 97 & 71 & 75 & 48 & 60 & 58 & 66 & 67 & 86 \\
\hline Picloram+2,4-D & $0.28+2.2$ & 70 & 95 & 71 & 71 & 58 & 70 & 57 & 62 & 67 & 83 \\
\hline Picloram+2,4-D & $0.42+1.1$ & 77 & 97 & 82 & 84 & 65 & 72 & 69 & 72 & 71 & 91 \\
\hline Picloram+2,4-D & $0.42+1.6$ & 63 & 96 & 85 & 93 & 69 & 82 & 68 & 74 & 78 & 95 \\
\hline Picloram+2,4-D & $0.42+2.2$ & 90 & 99 & 75 & 86 & 64 & 66 & 68 & 59 & 73 & 93 \\
\hline Picloram+2,4-D & $0.56+1.1$ & 86 & 96 & 89 & 92 & 70 & 74 & 71 & 75 & 82 & 94 \\
\hline Picloram+2,4-D & $0.56+1.6$ & 78 & 96 & 85 & 97 & 81 & 62 & 64 & 73 & 73 & 97 \\
\hline Picloram+2,4-D & $0.56+2.2$ & 71 & 96 & 86 & 96 & 84 & 73 & 76 & 75 & 78 & 96 \\
\hline $\operatorname{LSD}(0.05)$ & & 33 & 12 & 23 & 21 & 24 & 30 & 18 & 14 & 18 & 16 \\
\hline
\end{tabular}

Experiment at Valley City received only 4 annual picloram or picloram plus 2,4-D treatments and 7 biannual 2,4-D treatments and data are not included in the 48 month mean. 
eluent ' $A$ ', $1 \%$ acetic acid in water ( $v / v)$ and eluent ' $B$ ', $1 \%$ acetic acid in acetonitrile $(v / v)$ using a linear gradient of 5 to $80 \%$ ' $B$ ' in 25 $\mathrm{min}$. The detector was a variable wavelength spectrophotometer operated at $254 \mathrm{~nm}$. Retention time was approximately $9 \mathrm{~min}$. Data were quantified by comparing peak areas against standards of known concentrations. Analysis of fortified samples indicated the least detectable limit was $0.5 \mathrm{ppb}$.

Leafy spurge seedling susceptibility to picloram was determined in a petri dish bioassay. Ten $g$ soil samples were prepared as described in the bioassay experiment. Technical picloram at 2 to $1,000 \mathrm{ppbw}$ was added to 4 replicate subsamples of untreated soil from each location. Ten leafy spurge seeds were planted per dish just below the soil surface and the dishes were placed in a growth chamber. The temperature was $30 / 20^{\circ} \mathrm{C}$ (day/night) for the first week and $25 / 20^{\circ} \mathrm{C}$ (day/night) for the next 3 weeks with 80 to $90 \%$ relative humidity. A combination of fluorescent and incandescent bulbs provided $490 \mu \mathrm{E} \bullet \mathrm{m}^{-2} \bullet \mathrm{s}^{-1}$ during the $12 \mathrm{~h}$ day. These are the optimum conditions for leafy spurge seed germination and seedling growth (Bakke 1936). Petri dishes were rotated weekly and plants were watered as needed. The percentage of emerged seed- lings and seedling survival after 4 weeks was compared to the control.

Leafy spurge root segments $1,5,10$, and $20 \mathrm{~cm}$ long of uniform diameter were obtained from 2-year-old greenhouse grown plants. One root segment was planted $1.5 \mathrm{~cm}$ deep per $4 \mathrm{~cm}$ diam by $20 \mathrm{~cm}$ long conical pot which contained $200 \mathrm{~g}$ of a soil-less medium of peat, perlite, and vermiculite. Technical picloram at 0 to 1,000 ppbw was added to the soil-less medium. The growth chamber temperature was $25 / 20^{\circ} \mathrm{C}$ (day/night) with $50 \%$ relative humidity in a 16-h day. The number of emerged shoots was recorded 28 days after planting. A similar experiment was conducted using $200-\mathrm{g}$ soil samples from the 3 field locations and $10-\mathrm{cm}$ leafy spurge root segments. All growth chamber experimental designs were completely random with 4 replications and repeated, except the field soil study which was repeated 3 times. Data for leafy spurge control, seed germination, and regrowth from root segments were analyzed using the general linear models procedure (Stat. Anal. Syst. 1982).

Table 3. Picloram concentration from various annual application rates for 4 years at three locations in North Dakota as determined by a sunflower bioassay in 1982 through 1984 and HPLC in 1985.

\begin{tabular}{|c|c|c|c|c|c|c|c|c|c|}
\hline \multirow[b]{3}{*}{ Location } & \multirow[b]{3}{*}{ Depth } & \multirow{3}{*}{$\begin{array}{l}\text { Treatment } \\
\text { rate }\end{array}$} & \multicolumn{7}{|c|}{ Sampling date } \\
\hline & & & \multicolumn{2}{|c|}{1982} & \multicolumn{2}{|c|}{1983} & \multicolumn{2}{|c|}{1984} & \multirow{2}{*}{$\frac{1985}{\text { Sept }}$} \\
\hline & & & June & Aug & June & Aug & June & Aug & \\
\hline \multirow{16}{*}{ Sheldon } & (cm) & $(\mathrm{kg} / \mathrm{ha})$ & & & & ppbw & & & \\
\hline & $0-15$ & 0.28 & $<2$ & 102 & $<2$ & 12 & $<2$ & 55 & 20 \\
\hline & & 0.42 & $<2$ & 121 & $<2$ & 38 & $<2$ & 46 & 45 \\
\hline & & 0.56 & $<2$ & 182 & $<2$ & 45 & $<2$ & 66 & 59 \\
\hline & $15-30$ & 0.28 & $* *$ & $* * *$ & $* *$ & $* *$ & $<2$ & ** & 25 \\
\hline & & 0.42 & ** & $* * *$ & ** & $* *$ & $<2$ & ** & 52 \\
\hline & & 0.56 & ** & $* * *$ & ** & $* *$ & 15 & $* *$ & 30 \\
\hline & $30-60$ & 0.28 & ** & $* * *$ & $* *$ & $* *$ & ** & ** & 2 \\
\hline & & 0.42 & $* *$ & $* * *$ & $* *$ & $* *$ & ** & ** & $<1$ \\
\hline & & 0.56 & ** & $* * *$ & ** & $* *$ & ** & ** & 4 \\
\hline & $60-90$ & 0.28 & ** & $* * *$ & ** & ** & ** & ** & 3 \\
\hline & & 0.42 & ** & $* * *$ & $* *$ & $* *$ & ** & ** & 6 \\
\hline & & 0.56 & ** & $* * *$ & ** & $* *$ & ** & $* *$ & 18 \\
\hline & $90-120$ & 0.28 & ** & $* * *$ & ** & $* *$ & ** & ** & $<1$ \\
\hline & & 0.42 & ** & $* * *$ & ** & $* *$ & $* *$ & ** & 14 \\
\hline & & 0.56 & ** & $* * *$ & $* *$ & $* *$ & $*$ & $* *$ & 14 \\
\hline \multirow[t]{12}{*}{ Dickinson } & $0-15$ & 0.28 & $<2$ & $<2$ & $<2$ & 10 & $<2$ & 10 & 15 \\
\hline & & 0.42 & $<2$ & $<2$ & $<2$ & 13 & $<2$ & 13 & 19 \\
\hline & & 0.56 & $<2$ & 11 & 10 & 83 & $<2$ & 20 & 22 \\
\hline & $15-30$ & 0.28 & $* *$ & $* * *$ & $* *$ & $* *$ & 22 & $* *$ & 5 \\
\hline & & 0.42 & ** & $* * *$ & $* *$ & $* *$ & 34 & ** & 4 \\
\hline & & 0.56 & ** & $* * *$ & $* *$ & ** & 14 & ** & 3 \\
\hline & $30-60$ & 0.28 & ** & $* * *$ & ** & $* *$ & ** & ** & 2 \\
\hline & & 0.42 & ** & $* * *$ & ** & $* *$ & ** & ** & 3 \\
\hline & & 0.56 & ** & $* * *$ & ** & $* *$ & ** & $* *$ & ND \\
\hline & $60-90$ & 0.28 & ** & $* * *$ & ** & $* *$ & $* *$ & $* *$ & ND \\
\hline & & 0.42 & $* *$ & $* * * *$ & ** & $* *$ & ** & $* *$ & ND \\
\hline & & 0.56 & ** & $* * *$ & ** & $* *$ & ** & ** & ND \\
\hline \multirow[t]{15}{*}{ Valley City } & $0-15$ & 0.28 & ** & $<2$ & $<2$ & 102 & 22 & 64 & 20 \\
\hline & & 0.42 & ** & $<2$ & $<2$ & 86 & 65 & 126 & 47 \\
\hline & & 0.56 & ** & $<2$ & 31 & 95 & 55 & 105 & 30 \\
\hline & $15-30$ & 0.28 & ** & $* * *$ & $* *$ & $* *$ & ** & $* *$ & 20 \\
\hline & & 0.42 & ** & $* * *$ & $* *$ & ** & ** & ** & 16 \\
\hline & & 0.56 & ** & $* * *$ & $* *$ & ** & $* *$ & ** & 8 \\
\hline & $30-60$ & 0.28 & ** & $* * * *$ & $* *$ & $* *$ & $* *$ & $* *$ & 7 \\
\hline & & 0.42 & *** & $* * *$ & $* *$ & $* *$ & ** & ** & $<1$ \\
\hline & & 0.56 & $* *$ & $* * *$ & ** & $* *$ & ** & ** & 5 \\
\hline & $60-90$ & 0.28 & ** & $* * *$ & ** & ** & ** & ** & ND \\
\hline & & 0.42 & ** & $* * *$ & ** & $* *$ & $* *$ & $* *$ & $<1$ \\
\hline & & 0.56 & ** & $* * *$ & ** & $* *$ & ** & $* *$ & $<1$ \\
\hline & $90-120$ & 0.28 & ** & $* * *$ & ** & $* *$ & ** & $* *$ & ND \\
\hline & & 0.42 & ** & $* * *$ & ** & $* *$ & ** & $* *$ & 20 \\
\hline & & 0.56 & $* *$ & $* * *$ & $* *$ & $* *$ & $* *$ & $* *$ & 1 \\
\hline
\end{tabular}




\section{Results and Discussion}

Picloram at $0.28,0.42$, and $0.56 \mathrm{~kg} /$ ha provided 48,75 , and $90 \%$ leafy spurge control, respectively, after 5 annual applications when averaged across the Dickinson and Sheldon locations (Table 2). Control gradually improved over time with picloram at 0.42 and $0.56 \mathrm{~kg} / \mathrm{ha}$, but not at the $0.28 \mathrm{~kg} / \mathrm{ha}$ application rate. Leafy spurge control from similar picloram applications averaged 39,48 , and $59 \%$, respectively, following 4 annual treatments at Valley City.

Leafy spurge control was $51 \%$ following 8 biannual 2,4-D applications averaged over rate and location. Leafy spurge control gradually increased over time regardless of the 2,4-D application rate. However, Bybee and Messersmith (1976) reported that leafy spurge reestablished to the original density within 1 year after discontinuation of treatments that had been applied biannually for 4 to 5 years. Biannual 2,4-D treatment would be useful in areas where environmental conditions would prohibit picloram use but likely would only prevent leafy spurge seed production and spread with little change in area of the original infestation.

Leafy spurge control increased when 2,4-D was applied with picloram at 0.28 or $0.42 \mathrm{~kg} / \mathrm{ha}$ compared to picloram alone at similar application rates (Table 2). Control averaged 85 and $93 \%$ with picloram at 0.28 or $0.42 \mathrm{~kg} /$ ha plus $2,4-\mathrm{D}$ at 1.1 to $2.2 \mathrm{~kg} / \mathrm{ha}$, respectively, compared to 48 and $75 \%$, respectively, with similar picloram treatments applied alone. Picloram at $0.56 \mathrm{~kg} /$ ha plus 2,4-D provided $96 \%$ leafy spurge control and was similar to picloram at $0.56 \mathrm{~kg} /$ ha alone at $90 \%$ control. The benefit of applying 2,4-D with picloram for improved leafy spurge control decreased as the picloram rate increased. Leafy spurge control with picloram at 0.28 and $0.42 \mathrm{~kg} / \mathrm{ha}$ increased 37 and $18 \%$, respectively, when averaged over all 2,4-D rates compared to similar picloram treatments applied alone. Leafy spurge control did not improve as the 2,4-D rate was increased from 1.1 to $2.2 \mathrm{~kg} /$ ha in combination with picloram.

After 3 years of annual application of picloram at $0.56 \mathrm{~kg} / \mathrm{ha}$ alone or at 0.28 and $0.42 \mathrm{~kg} / \mathrm{ha}$ with $2,4-\mathrm{D}$ at 1.1 to $2.2 \mathrm{~kg} / \mathrm{ha}$ leafy spurge control was comparable to that from picloram applied once at $2.2 \mathrm{~kg} / \mathrm{ha}$ (Lym and Messersmith 1985b). Leafy spurge control with picloram at $2.2 \mathrm{~kg} / \mathrm{ha}$ averaged 76 compared to $71 \%$ with picloram applied annually either at $0.56 \mathrm{~kg} / \mathrm{ha}$ alone or at 0.28 and $0.42 \mathrm{~kg} / \mathrm{ha}$ with 2,4-D at 1.1 to $2.2 \mathrm{~kg} / \mathrm{ha}$. However, the combined 3 -year annual treatment costs were 25,55 and $36 \%$ lower, respectively, compared to picloram applied once at $2.2 \mathrm{~kg} / \mathrm{ha}$. Furthermore, a retreatment following the picloram at $2.2 \mathrm{~kg} /$ ha treatment would be necessary after the third year to maintain satisfactory leafy spurge control (Lym and Messersmith 1985a).

Picloram did not accumulate in the top $15 \mathrm{~cm}$ of the soil following annual application regardless of soil type or annual precipitation (Table 3). In general, picloram was not detected above 2 ppbw in the top $15 \mathrm{~cm}$ of the soil profile 12 months following application except at the Valley City site in 1984. The amount of picloram detected in August of each year varied with the annual precipitation received from June to August; generally, more picloram remained in the upper $15 \mathrm{~cm}$ in drier than wet years (Tables 1 and 3). More picloram residue was retained in the upper $15 \mathrm{~cm}$ of soil at Valley City than at Dickinson and Sheldon probably because the Valley City soil contained more organic matter (Bauer et al. 1972; Herr et al. 1966; Phillips and Feltner 1972; and Scifres et al. 1971a). The greater retention of picloram at Valley City also could explain the reduced leafy spurge control compared to the other 2 sites. Less picloram may have been available for root absorption especially at lower soil levels, thus limiting long-term leafy spurge root control.

Picloram was detected throughout the entire $120-\mathrm{cm}$ soil profile sampled in 1985 at Sheldon and Valley City, but not at Dickinson (Table 3). In general, the picloram concentration in lower soil depths increased directly with the sand content of the soil. The soil at Sheldon has $71 \%$ sand and there was $14 \mathrm{ppbw}$ picloram at 120 $\mathrm{cm}$, while the soil at Dickinson has only $17 \%$ sand and no picloram was detected below $60 \mathrm{~cm}$ (Table 1). Picloram residues were not uniformly distributed throughout the soil profile. Picloram moves through soil in concentration pulses following high precipitation and is relatively immobile during drought periods (Neary et al. 1985). Thus, higher picloram residue at the 90 to $120 \mathrm{~cm}$ level than at 30 to 60 or 60 to $90 \mathrm{~cm}$ at Valley City and Sheldon, respectively, is probably due to concentration pulses. Generally, concentration pulse patterns at lower depths are of lower magnitude and delayed compared to upper soil levels.

Since picloram did not accumulate in the soil profile after 4 annual applications of $0.56 \mathrm{~kg} / \mathrm{ha}$ or less, this treatment program should not be considered an environmental hazard when herbicide label directions are followed. Previous studies have shown that residue in runoff water from picloram application of $0.56 \mathrm{~kg} / \mathrm{ha}$ or less was of little consequence especially 10 to 20 days after application (Bauer et al. 1972; Scifres et al. 1969, 1971b; Trichell et al. 1968). The possibility of accidental contamination of open wells or surface water still exists if the applicator is careless. Since picloram should not be applied in areas where the water table is within $3 \mathrm{~m}$ or less of the soil surface, introduction into underground water by leaching does not seem likely.

A picloram concentration of 500 and $250 \mathrm{ppbw}$ was required to reduce leafy spurge seedling emergence and survival by at least $50 \%$, respectively (Table 4). A picloram concentration of 8 to 32 ppbw tended to increase leafy spurge emergence compared to the control and did not affect seedling survival. Bowes and Thomas (1978) found that picloram concentrations up to $1,000 \mathrm{ppbw}$ did not affect leafy spurge seed germination in the lab. Apparently, leafy spurge seed germination is not inhibited by picloram, but subsequent growth required for emergence is decreased at picloram concentrations of 500 ppbw or more.

Picloram at $125 \mathrm{ppbw}$ was required to decrease seedling survival and $5 \%$ of the leafy spurge seedlings that emerged at $1,000 \mathrm{ppbw}$

Table 4. Leafy spurge seedling emergence and survival after 4 weeks in three North Dakota soil types and at various picloram concentrations.

\begin{tabular}{|c|c|c|c|c|c|c|c|c|}
\hline \multirow[b]{3}{*}{ Picloram concentration } & \multicolumn{6}{|c|}{ Soil location } & & \\
\hline & \multicolumn{2}{|c|}{ Sheldon } & \multicolumn{2}{|c|}{ Dickinson } & \multicolumn{2}{|c|}{ Valley City } & \multicolumn{2}{|c|}{ Mean } \\
\hline & Emergence & Survival & Emergence & Survival & Emergence & Survival & Emergence & Survival \\
\hline \multicolumn{9}{|l|}{$\overline{(p p b w)}$} \\
\hline 0 & 75 & 100 & 85 & 100 & 60 & 100 & 73 & 100 \\
\hline 8 & 90 & 75 & 100 & 100 & 100 & 100 & 97 & 100 \\
\hline 16 & 90 & 97 & 100 & 96 & 100 & 96 & 97 & 100 \\
\hline 32 & 100 & 98 & 90 & 95 & 70 & 95 & 87 & 96 \\
\hline 64 & 60 & 89 & 75 & 89 & 70 & 86 & 68 & 88 \\
\hline 125 & 80 & 79 & 80 & 72 & 65 & 52 & 75 & 68 \\
\hline 250 & 80 & 50 & 60 & 56 & 70 & 34 & 70 & 47 \\
\hline 500 & 40 & 29 & 40 & 19 & 50 & 9 & 43 & 19 \\
\hline 1000 & 40 & 6 & 40 & 4 & 50 & 4 & 43 & 5 \\
\hline LSD (0.05) & 30 & 28 & 27 & 16 & 31 & 32 & 19 & 17 \\
\hline
\end{tabular}


picloram grew for at least 4 weeks in a growth chamber (Table 4). A higher mortality rate may be expected under field conditions where environmental conditions are less favorable for survival than in the growth chamber. However, less than $100 \mathrm{ppbw}$ of picloram generally remained in the upper $15 \mathrm{~cm}$ of soil 3 months after application, so the herbicide residue probably would not limit the growth of leafy spurge seedlings. Indeed, the low concentration of picloram remaining in the soil 3 to 12 months after application may stimulate leafy spurge seed germination.

Table 5. Leafy spurge shoot regrowth from root segments of four lengths exposed to various picloram concentrations for 28 days.

\begin{tabular}{lcccc}
\hline \hline \multirow{2}{*}{$\begin{array}{l}\text { Picloram } \\
\text { concentration }\end{array}$} & $1 \mathrm{~cm}$ & $5 \mathrm{~cm}$ & $10 \mathrm{~cm}$ & $20 \mathrm{~cm}$ \\
\cline { 2 - 4 } ppbw & \multicolumn{4}{c}{ Original root length } \\
0 & 6 & 38 & 38 & 81 \\
125 & 0 & 13 & 13 & 6 \\
250 & 0 & 0 & 0 & 0 \\
500 & 0 & 0 & 0 & 0 \\
LSD $(0.05)=17$ & & & & \\
\hline
\end{tabular}

Lower picloram concentrations were required to control leafy spurge regrowth from roots than from seeds (Tables 4 and 5). More leafy spurge shoots were produced from $20 \mathrm{~cm}$ long root segments than shorter segments, but 5 and $10 \mathrm{~cm}$ long segments provided a similar number of new shoots when grown in a soil-less plant mixture. Regrowth was reduced when picloram at 125 ppbw was added to the soil-less medium, and no regrowth occurred at higher picloram concentrations.

Leafy spurge shoot regrowth increased as root segment length increased, but segment length had little effect on the regrowth response to picloram (Table 5). Leafy spurge shoots grew from $81 \%$ of the $20 \mathrm{~cm}$ root segments compared to $6 \%$ from $1 \mathrm{~cm}$ root segments, but regrowth fell to 6 and $0 \%$, respectively, when treated with 125 ppbw picloram in the soil-less medium.

Regrowth from 10-cm leafy spurge segments declined as picloram concentration increased in soil from the 3 experimental sites, but not as rapidly as when grown in the soil-less medium (Table 6).

Table 6. Leafy spurge shoot regrowth from $10 \mathrm{~cm}$ root segments in three North Dakota soils exposed to various picloram concentrations for 28 days.

\begin{tabular}{lcccc}
\hline \multirow{2}{*}{$\begin{array}{l}\text { Picloram } \\
\text { concentration }\end{array}$} & \multicolumn{3}{c}{ Soil location } \\
\cline { 2 - 4 } ppbw & Sheldon & Dickinson & Valley City & Mean \\
\hline 0 & - & $(\%$ of roots & with shoots $)$ & \\
64 & 75 & 63 & 63 & 67 \\
125 & 50 & 25 & 38 & 38 \\
250 & 25 & 38 & 50 & 38 \\
500 & 13 & 13 & 38 & 21 \\
1000 & 0 & 25 & 13 & 13 \\
LSD & 38 & 0 & 0 & 13 \\
\hline
\end{tabular}

Leafy spurge regrowth averaged $67 \%$ (at all 3 locations) in untreated soil, but averaged 13 to $38 \%$ in soil treated with picloram concentrations of 64 to $1,000 \mathrm{ppbw}$. The picloram residue concentration detected in soil may be high enough through August to reduce leafy spurge regrowth from roots (Table 3), but generally were low enough that at least half of the newly emerged shoots would survive (Table 6).

The addition of 2,4-D to picloram at 0.28 to $0.42 \mathrm{~kg} / \mathrm{ha}$ improved leafy spurge control, but did not affect control from picloram at $0.56 \mathrm{~kg} / \mathrm{ha}$. Picloram at 0.28 to $0.56 \mathrm{~kg} / \mathrm{ha}$ did not accumulate in the upper soil profile after 5 annual applications regardless of location. Control was slightly less and picloram residues were higher in soil with high organic matter contents, and organic matter apparently was the only soil characteristic that affected leafy spurge control. Picloram at 250 to $500 \mathrm{ppbw}$ or greater was needed to decrease leafy spurge seedling emergence and growth by $50 \%$, but leafy spurge shoot regrowth from root segments was reduced by picloram at $64 \mathrm{ppbw}$.

Picloram plus 2,4-D at 0.28 plus $1.1 \mathrm{~kg} / \mathrm{ha}$ applied annually over time provided similar leafy spurge control to picloram at 0.56 $\mathrm{kg} / \mathrm{ha}$ applied annually or picloram at $2.2 \mathrm{~kg} / \mathrm{ha}$ applied once. The combination treatment over a few years can increase a landowner's net income by $50 \%$ or more through reduced herbicide cost and increased forage production as compared to less frequent treatment with higher herbicide rates. The potential for unacceptable environmental contamination by picloram should be much smaller from low rates applied annually compared to high rates applied less frequently.

\section{Literature Cited}

Alley, H.P., R.E. Vore, and T.D. Whitson. 1983. A summary of four years repetitive herbicide treatments for control of leafy spurge (Euphorbia esula L.). Proc. West. Soc. Weed Sci. 36:87-93.

Bakke, A.L. 1936. Leafy spurge, Euphorbia esula L. Iowa Agr. Exp. Sta. Bull. 198.

Bauer, J.R., R.W. Bovey, and M.G. Merkle. 1972. Concentration of picloram in runoff water. Weed Sci. 20:309-313.

Bovey, R.W., E. Burnett, C. Richardson, M.G. Merkle, J.R. Bauer, and W.G. Knisel. 1974. Occurrence of 2,4,5-T and picloram in surface runoff water in the Blacklands of Texas. J. Environ. Qual. 3:61-64.

Bovey, R.W., E. Burnett, C. Richardson, J.R. Bauer, M.G. Merkle, and D.E. Kissel. 1975. Occurrence of 2,4,5-T and picloram in subsurface water in the Blacklands of Texas. J. Environ. Qual. 4:103-106.

Bowes, G.G., and A.G. Thomas. 1978. Longevity of leafy spurge seeds in the soil following various control program. J. Range Manage. 31:137-140.

Bybee, T.A., and C.G. Messersmith. 1976. Factors affecting leafy spurge recstablishment. Proc. North Central Weed Con. Conf. 31:37.

Herr, D.E., E.W. Stroube, and D.A. Ray. 1966. The movement and persistence of picloram in soil. Weed Sci. 14:248-250.

Johnson, J.E. 1984. North Dakota farmland values and rentals. North Dakota Farm Res. 42(1):25-30.

Lym, R.G., and C.G. Messersmith. 1985a. Leafy spurge control with herbicides in North Dakota: 20 year summary. J. Range Manage. 38:149-154.

Lym, R.G., and C.G. Messersmith. 1985b. Leafy spurge control and improved forage production with herbicides. J. Range Manage. 38:386-391.

Neary, D.G., P.B. Bush, J.E. Douglass, and R.L. Todd. 1985. Picloram movement in an appalachian hardwood forest watershed. J. Environ. Qual. 14:585-592.

Phillips, W.M., and K.C. Feltner. 1972. Persistence and movement of picloram in two Kansas soils. Weed Sci. 20:110-116.

Scifres, C.J., O.C. Burnside, and M.K. McCarty. 1969. Movement and persistence of picloram in pasture soils of Nebraska. Weed Sci. $17: 486-488$.

Scifres, C.J., R.R. Hahn, J. Diaz-Colon, and M.R. Merkle. 1971b. Picloram persistence in semiarid rangeland soils and water. Weed Sci. 19:381-384.

Scifres, C.J., R.R. Hahn, and M.G. Merkle. 1971a. Dissipation of picloram from vegetation of semiarid rangelands. Weed Sci. 19:329-332.

Scifres, C.J., H.G. McCall, B. Maxey, and H. Tai. 1977. Residual properties of 2,4,5-T and picloram in sandy rangeland soils. J. Environ. Qual. 6:36-42.

Smith, A.E., and LJ. Milward. 1983. Comparison of solvent systems for the extraction of diclofop acid, picloram, simazine, and triallate from weathered field soils. J. Agr. Food Chem. 31:633-637.

Statistical Analysis System Institute. 1982. SAS User's Guide: Statistics. Cary, NC.

Trichell, D.W., H.H. Morton, and M.G. Merkle. 1968. Loss of herbicides in runoff water. Weeds 16:447-449.

Wells, M.J.M., J.L. Michael, and D.G. Neary. 1984. Determination of picloram in soil and water by reversed-phase liquid chromatography. Arch. Environ. Contam. Toxicol. 13:231-235. 